and things is astonishing. We have heard it declared, by those who are well acquainted with him, that he knows and recollects personally every medical officer of the army whom he has once seen. His extensive personal knowledge of civil medical men is remarkable. To a wise judgment he adds a singular quickness and acuteness of perception. Let a subject be ever so intricate and perplexed, he at once comes to the difficulty and solves it. His acts are marked by the absence of all indecision or hesitation. His popularity with the army medical officers is very great; ever accessible and ready to serve the interests of all to the best of his ability and their deserts, and his conduct has ever been marked by the most liberal hospitality to his brother medical officers, particularly on their return from foreign stations. He has ever exerted himself to promote good feeling between military and civil medical men, promoting the interchange of kindly offices between them by every means in his power. By precepts and by example he has laboured to infuse into military surgeons a desire to renew their professional knowledge at all proper opportunities. He has himself attended as a pupil in the medical class-rooms of the metropolis since he became directorgeneral! His efforts in the cause of medical education have been unceasing; and by gradually raising the standard of qualification for the medical service of the army, he has raised this important branch of the profession to a high pitch of excellence.

We have said nothing more than the simple truth in this necessarily brief sketch, but we have said enough to show that Sir James $M^{6}$ Grigor possesses qualities sufficiently eminent to fit him for greatness in any station of life. He has long been one of the pillars of the profession, and whenever he may pass from amongst us, it will be difficult, if not impossible, to find a successor equal to him in every respect.

\section{MEDICAL PROTECTION SOCIETIES.}

[FROM A CORRESPONDEMT.]

THE Medical Protection Office, as itwas called, was started under the sole management of one individual, but ostensibly under the patronage, if not the guardianship, of several re spectable men in general practice. However this may be, it is certainly true that a very great number of persons became subscribers to the office, under the idea that some responsibility rested on the shoulders of those whose names were attached to the prospectus issued from the office. The office was to protect medical men from illegal practitioners; to establish a benevolent fund; and collect the debts of the members at a small per centage. The anmual fee was a guinea. From the first, The Lancer questioned both the value and stability of the office. At the end of twenty-eight months, the office stops payment. A meeting is called, and a statement is read by the "managing director," which is chiefly remarkable for its want of explanation. Twelve hundred members had enrolled their names on the list; $\$ 15,000$ had been collected; the average commission on which had been ten per cent. Yet it was stated at the meeting, in round numbers, that $£ 2500$ was owing to members out of the $£ 15,000$ collected. No satisfactory balance-sheet was made out-no one but the "director" acknowledges responsibility, and thus the office may be fairly said to have sunk. Certain gentlemen, however, have formed themselves into a committee to carry on the office, still retaining the late "director" as an official; but only "as a servant." These gentlemen hold out hopes of paying off the arrears due to members, and still carrying on the office at a profit. We shall see. It is now eagerly asked, by all those interested, "What has become of the large sums of money subscribed and paid to the office?" "Is there no responsibility resting on the heads of those who lent their names as trustees, \&c.?" I leave others to answer these questions; but an answer is imperatively demanded. Not a shilling, it would appear, has been paid for any benevolent purpose; and the protection given to medical men has amounted to worse than nothing. A balance-sheet is universally called far.

Another Society has started, in which the committee are liable to the subscribers; their objects are identical with those of the defunct office, but there is more of a business character about their proceedings. A short time will enable us to speak a little further on the subject.

\section{THE INTESTINAL DISCHARGES IN CHOLERA.} To the Editor of ThE LANCET.

Srr,-It is due to Mr. Simon to state that I received a note from that gentleman, in reply to my remarks upon an extract from his last pathological lecture, the substance of which note, by his permission, is at my disposal.

Mr. Simon admits that the term "serum" is, to say the least, "an in-exact expression ;" and that "the usage is beyond doubt objectionable, as it may give rise to misapprehension."

Mr. Simon further states, that the title-sheet of his reprint, happening still to be within his reach when he read what he is pleased to call my "friendly criticism," he was enabled to add to his list of errata-for "serum," read "fluid." The substitution of this negative phrase necessarily removes, as he very justly observes, "the paragraph out of debateable ground."

Mr. Simon is not sure that he should equally assent to my conclusions in respect to the non-albuminous state of the "fluid," as he has frequently, in fact always, found it albuminous, though his observations, he admits, may have been mado in a narrower sphere than my own.

In conclusion, I beg to acknowledge the very courteous and truly scientific spirit which characterized Mr. Simon's communication.

Hull, Oct. 4, 1850

I am, Sir, your obedient servant,

Grorge Low THER.

P.S.-I may add, that within the last twenty-four hours I have had a fatal case, presenting each symptom of the malignant type of this disease. The pathognomonic discharges were submitted to a more extended examination, but with the usual results.

\section{POISONING BY DENTISTS. To the Editor of The LANCET.}

SIR,-Pray find room for a word of caution, which, admitted to your pages, may chance to save life, and economize, for the newspaper press, on the penny tariff of a " poison paragraph." It is a case, believe me, Sir, for " urgency," without debate. Cer tain dentists-be it known, through you, to all with teeth in their heads-are in the habit of "stopping" with arsenical paste. Of the "great scientific fact" here announced, I was first informed by a lady, in whose mouth this virulent poison had been made " at home" some few days back, and who has subsequently consulted me for the relief of symptoms " to match." This "improved method of dentism," which, it would appear, is of transatlantic origin, has been in vogue for more than six months past, and is already reported by its professors of paramount necessity in their art. "Stopping the teeth" with arsenic! Denounce it, Sir, in plain medical phrase, as just "stopping the breath!" Who, after this, your counterblast to poison for the toothache, would hope to succeed in "stopping your mouth" at an inquest ensuing on death from the dentist? I am, Sir, your fellow-labourer.

London, Oct. 5, 1850. MaXILLA, (J. A. W.)

\section{THE EDINBURGH MONTHLY JOURNAL AND ITS} CONTRIBUTORS.

To the Editor of Tax Lancer.

Sin,-In the September number of the Edinburgh Monthly Journal of Medical Science, in place of an apology, which was long past due, a notice of the Correspondence of THE LANCET as to Dr. Simpson's conduct as editor of the Monthly, appeared, pleading justification for altering \&c. the opinions of a contributor without his consent-nearly in the terms, and after the style, of Dr. Simpson's letter in 'The Lancex.

Considering that, in common justice, the journal admitting such a notice would, undoubtedly, admit an answer from the person one of its functionaries had wronged, I addressed a defence, giving a summary of the wrongs done to me, to Dr. Robertson, behind whom the junto fight, but this gentleman refuses to give it insertion.

It would only be a needless waste of your useful pages to re mark, at any length, on this new injustice, to colour somewhat more deeply the odium which the Edinburgh Monthly Journal has secured to itself by unscrupulously claiming the right to alter the opinions and facts of contributors without consent. But surely it is ungenerous and unjust to deny space in a journal for correction or defence. which the conduct of its editors force upon any one.

Carluke, Oct. 1950

I am, Sir, yours sincerely, D. R. RANKIN. 